\title{
Dostosowanie polskich doświadczeń w zakresie nieniszczącej oceny wytrzymałości betonu do wymagań PN-EN
}

\author{
Adapting Polish experience in the non-destructive evaluation \\ of the strength of concrete to requirements PN-EN
}

\section{Streszczenie}

Poprawa jakości produkowanego betonu nie zawsze przekłada się na jakość wykonania elementów konstrukcji. Zła jakość betonu była przyczyną wielu awarii i katastrof obiektów budowlanych.

Rosnące wymagania dotyczące jakości konstrukcji żelbetowych stwarzają m.in. potrzebę stosowania metod kontroli „in situ”. Wśród takich metod kontroli prym wiodą nieniszczące metody badawcze, szczególnie wytrzymałości betonu.

W artykule przedstawiono analizę zagrożeń bezpieczeństwa w budownictwie oraz próbę dostosowania wieloletnich polskich doświadczeń w zakresie nieniszczącej oceny wytrzymałości betonu - metod sklerometrycznych - do wymagań PN-EN.

Słowa kluczowe: : wytrzymałość betonu, metody nieniszczące, metody sklerometryczne

\section{Abstract}

The improvement of the quality of produced concrete not always transfers itself into the quality of the workmanship of structural elements. The poor quality of concrete caused many damages and disasters of civil structures.

Growing of the requirements concerning the quality of reinforced concrete structures among others need of applying methods of monitoring "in situ". Non-destructive research methods are the leader among such methods of monitoring, particularly strengths of concrete.

In the article was described analysis of safety threats in the construction and attempt to adapt long-standing Polish experience in the non-destructive evaluation of the strength of concrete - sclerometric methods - to requirements $\mathrm{PN}-\mathrm{EN}$.

Keywords: concrete strength, non-destructive methods, sclerometric methods

\section{Wstęp}

Stosowane obecnie w Polsce nowoczesne technologie wykonywania żelbetowych konstrukcji obiektów budowlanych na ogół spełniają wysokie wymagania na poziomie światowym. Jednak, ze względu na duży zakres i różnorodność realizowanych obiektów budowlanych występują różnorodne problemy projektowe, realizacyjne i eksploatacyjne.

Niemal wszystkie obiekty o konstrukcji żelbetowej wykonywane są w technologii monolitycznej, wykorzystującej nowoczesne techniki deskowaniowe. Szacuje się, że poniżej $20 \%$ obiektów wykonywanych jest w technologii prefabrykowanej lub mieszanej prefabrykowano-monolitycznej.

Obecnie betony konstrukcyjne do realizowanych obiektów wykonywane są w ponad $70 \%$ w wytwórniach z zachowaniem kontroli jakości produkcji betonu. Pomimo wzrostu poziomu jakości produkowanego betonu w nowoczesnych warunkach, jego jakość w elementach konstrukcji obiektów jest często znacznie gorsza. W celu jej polepszenia niezbędne są dalsze prace nad prawidłowością realizacji w zakresie tech- nologii, techniki i organizacji, z wykorzystaniem elementów zespolonych oraz nowe i skuteczne metody kontroli „in situ”.

Rosnące wymagania dotyczące jakości konstrukcji żelbetowych oraz ciągły postęp w budownictwie stwarzają potrzebę stosowania nowych, coraz bardziej zaawansowanych technologii i metod kontroli "in situ”.

Wśród metod kontroli „in situ” największe znajdują różnorodne nieniszczące metody badawcze ukierunkowane i przystosowane do rozwiązywania i kontroli realizacji wyżej wymienionych problemów, a szczególnie wytrzymałości betonu.

Ponadto na potrzebę szerokiego stosowania nieniszczących metod badawczych podczas realizacji i eksploatacji wskazuje zbyt duża liczba zagrożeń bezpieczeństwa i awarii konstrukcji żelbetowych.

W referacie przedstawiono analizę zagrożeń bezpieczeństwa w budownictwie oraz dostosowanie wieloletnich polskich doświadczeń w zakresie nieniszczącej oceny wytrzymałości betonu do wymagań PN-EN. 


\section{Analiza zagrożeń i awarii konstrukcji żelbetowych}

Zła jakość i trwałość materiałów oraz niezawodność konstrukcji budowlanych w decydujący sposób wpływają na powstawanie zagrożeń, awarii i katastrof budowlanych. Jak wykazały wieloletnie analizy zagrożeń, awarii i katastrof budowlanych prowadzone przez Instytut Techniki Budowlanej, materiały budowlane oraz połączenia konstrukcyjne stanowiły bardzo ważny czynnik w powstawaniu zagrożeń, awarii i katastrof. Zła jakość materiałów była przyczyną zagrożeń, awarii i katastrof $\mathrm{w}$ różnych typach konstrukcji budowlanych oraz różnych budynkach lub budowlach inżynierskich.

Rodzaje konstrukcji budowlanych w jakich wystąpiły zagrożenia, awarie i katastrofy w ostatnich 40 latach w Polsce pokazano na rysunku 1 .

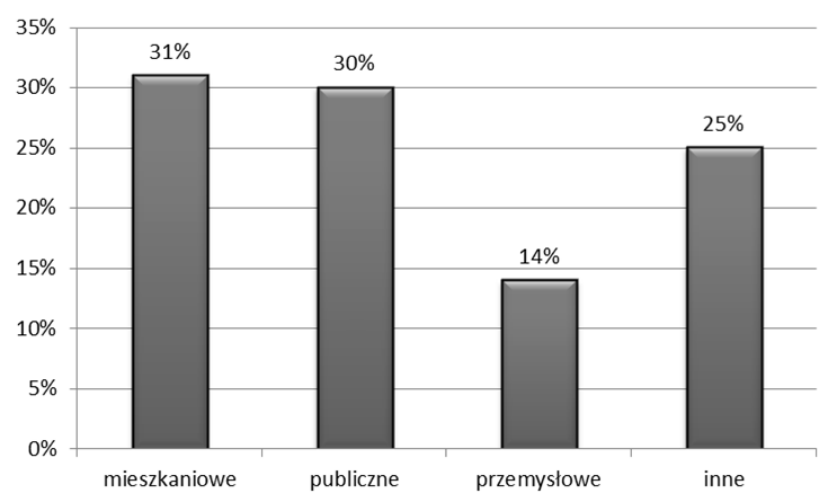

Rys. 1. Udział procentowy awarii i katastrof w latach 1962-2013 według podziału na rodzaje budownictwa.

Fig. 1. Damages and disasters in the period 1962-2013 according to construction type

Suma procentów w poszczególnych kolumnach może być mniejsza od 100 ze względu na nie ujęcie wszystkich rodzajów przypadków, lub może być większa od 100 ze względu na rozległy charakter awarii lub katastrof obejmujący kilka typów technologii lub elementów.

Typy konstrukcji budowlanych w jakich wystąpiły zagrożenia, awarie i katastrofy w ostatnich 40 latach w Polsce pokazano na rysunku 2.

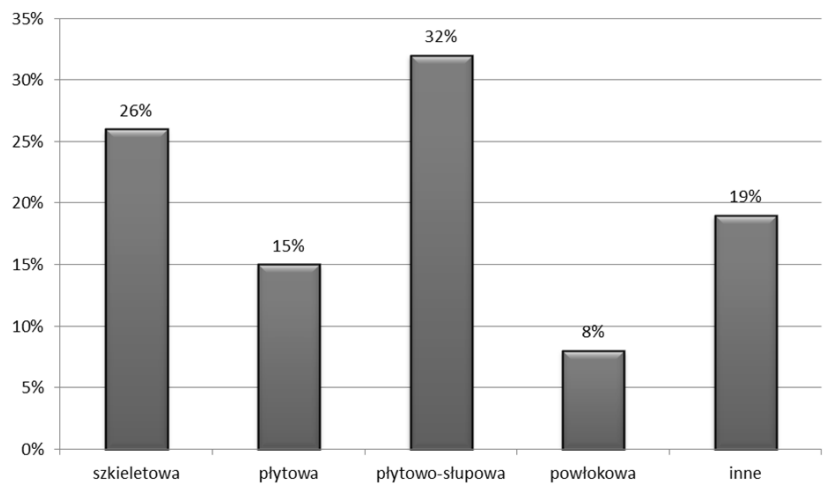

Rys. 2. Udział procentowy awarii i katastrof w latach 1962-2013, według podziału na typy konstrukcji budowlanych

Fig. 2. Damages and disasters in the period 1962-2013 according to structure type

Udział procentowy zagrożeń, awarii i katastrof powstałych z powodu złych materiałów pokazano na rysunku 3.

Zgodnie z aktualnymi przepisami międzynarodowymi, żelbetowe wyroby i elementy powinny posiadać odpowiednie cechy fizyczne i wytrzymałościowe pozwalające na spełnienie wymaganych stanów granicznych nośności i użyt-

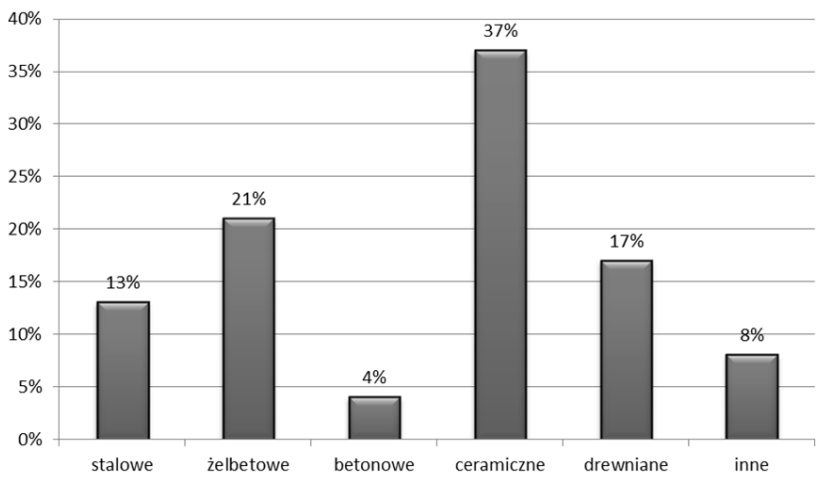

Rys. 3. Udział procentowy awarii i katastrof w latach 1962-2013 według podziału ze względu na materiały

Fig. 3. Damages and disasters in the period 1962-2013 according to applied materials

kowalności w zaprojektowanych obiektach budowlanych przez cały okres ich eksploatacji $[8,9]$.

Do oceny cech fizycznych i wytrzymałościowych w różnych fazach realizacji i eksploatacji coraz szerzej stosowane są metody nieniszczące.

Złożoność zagadnień związanych z bezpieczeństwem, niezawodnością i trwałością nowoczesnych konstrukcji żelbetowych w warunkach użytkowania wymaga rozwoju i doskonalenia specjalistycznych metod badawczych.

Diagnostyka i ocena elementów żelbetowych wymaga stosowania optymalnych metod badawczych "in situ", pozwalających na ocenę stanów granicznych obiektu budowlanego z dostateczną dokładnością w całym okresie realizacji i eksploatacji.

Generalnie, właściwości wyrobów, elementów i obiektów budowlanych według przepisów Unii Europejskiej ustalane są przez wymagania podstawowe, określane normami i aprobatami technicznymi $[3,5,7,8]$.

Właściwości wyrobów, elementów i obiektów budowlanych pozwalają na ocenę bezpieczeństwa, trwałości i niezawodności konstrukcji budowlanych. Dotyczy to także konstrukcji żelbetowych zarówno w czasie realizacji jak i w czasie eksploatacji.

\section{Niezawodność i trwałość konstrukcji żelbetowych}

Niezawodność elementów i konstrukcji żelbetowych wymaga aby nie były przekroczone stany graniczne elementów lub całych konstrukcji w obszarach najbardziej obciążonych

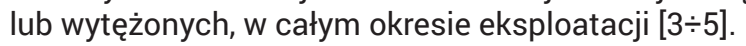

Stany graniczne nośności konstrukcji żelbetowych lub ich elementów wyrażają generalnie nierówności typu:

$$
S_{d} \leq R_{d}
$$

gdzie:

$S_{d}$ - obliczeniowa wielkość sił wewnętrznych,

$R_{d}$ - obliczeniowa nośność.

Natomiast stany graniczne użytkowalności konstrukcji, najczęściej ugięcia, zarysowania, odkształcenia, itp. wyrażają nierówności typu:

$$
E_{\mathrm{d}} \leq C_{\mathrm{d}}
$$

gdzie:

$E_{\mathrm{d}}$ - odkształcenia, ugięcia, szerokości rozwarcia rys, względnie inne parametry użytkowalności

$C_{d}$-wartości graniczne kryterium użytkowalności konstrukcji

Wytrzymałości charakterystyczne materiałów $f_{k} w$ eksploatowanych konstrukcjach przyjmować należy zgodnie z badaniami w naturze. 


\section{Zakres nieniszczących metod badań}

Do badań i kontroli wymienionych cech elementów w nowoczesnych konstrukcjach żelbetowych, wpływających na trwałość, ocenę nośności i niezawodności konstrukcji udoskonalane i rozwijane są $\mathrm{m}$. in. następujące specjalistyczne metody:

- ultrasonograficzne i sklerometryczne do ocen cech wytrzymałościowych i strukturalnych betonu w elementach,

- ultrasonograficzne i emisji akustycznej do ocen jednorodności i struktury betonu,

- elektryczne i elektrochemiczne do ocen wilgotności i korozji betonu,

- interferometrii do ocen struktury betonu w konstrukcji,

- holograficzne i magnetyczne do ocen struktury i wtrąceń w betonie wbudowanym,

- radiologiczne do ocen wilgotności i ciężaru betonu w konstrukcji,

- radarowe i termograficzne do ocen struktury elementów,

- radiograficzne z wykorzystaniem betatronów i mikrotronów, tomografii komputerowej, radiometryczne (gamma), oporu elektromagnetycznego, elektroakustyczne, spektroskopii, przepuszczalności gazu, transmisji ciepła, optyczne, itp. do ocen innych wybranych ważnych cech betonu i ich zmiany w czasie oraz położenia i ilości zbrojenia w elementach żelbetowych.

\section{Badania jakości betonu w elementach i konstrukcjach budowlanych}

\section{Charakterystyka metod badawczych}

Metody te są metodami pośrednimi, opartymi na zależnościach empirycznych pomiędzy mierzonymi wielkościami fizycznymi, a poszukiwanymi cechami materiałów. Metody te wymagają zatem wstępnego skalowania aparatury pomiarowej i urządzeń badawczych.

Do normowej oceny zmian wytrzymałości betonu w elementach i konstrukcjach stosuje się najczęściej nienisz-

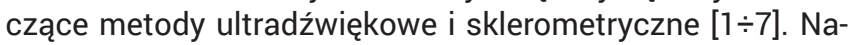
tomiast do oceny trwałości, niezawodności oraz stanów granicznych elementów i konstrukcji (według wzorów 1 i 2), wykonanych według nowoczesnych technologii stosuje się w Polsce od szeregu lat nieniszczące metody zgodnie z normami i instrukcjami $[1 \div 15]$.

W badaniach nieniszczących betonu wielką rolę odgrywają dobory właściwych zależności korelacyjnych. Jak wykazała dotychczasowa praktyka, zależności empiryczne (korelacyjne) są bardzo zróżnicowane, a ich błędne stosowanie obniża dokładność oceny nawet do ok. 100\%.

Zmiany wytrzymałości i jednorodność betonu określa się za pomocą metod nieniszczących i statystycznej analizy wyników pomiarów, w oparciu o zależności empiryczne ważne dla danego rodzaju betonu w badanej konstrukcji.

Dotychczas ocenę wytrzymałości gwarantowanych betonu $f_{c}{ }^{G}\left(R_{b}{ }^{G}\right)$ i klasy betonu przeprowadza się $w$ zależności od liczby pomiarów (lub odwiertów). Przy statystycznej ocenie gwarantowane wytrzymałości określa się z zależności empirycznych, ważnych dla określonych technologii betonu, jako wytrzymałości minimalne.

Według dotychczasowych polskich wymagań, dla zapewnienia oceny wytrzymałości betonu z wymaganą technicznie dokładnością (błąd oceny nie większy niż 20\%) dokładność związku empirycznego powinna wykazywać współczynnik korelacji większy od 0,75 lub względne kwadratowe odchylenie przy doborze krzywej hipotetycznej powinna być mniejsze $12 \%$ [1 $\div 15]$.
Dotychczas w badaniach diagnostycznych w Polsce stosowało się często przybliżony sposób wyznaczania związków empirycznych.

Powszechnie jest uznane, że zależności empiryczne pomiędzy wytrzymałością betonu, a wielkościami mierzonymi metodami nieniszczącymi są zależne od wielu parametrów charakteryzujących badany beton w konstrukcji [1 $\div 15]$.

Rozwój technologii betonu oraz stosowanie coraz to nowych składników do jego produkcji wpływa zasadniczo na charakter i przebieg powyższych zależności.

Opracowano szereg zależności służących do nieniszczącej kontroli betonu „in situ", które są wykorzystywane

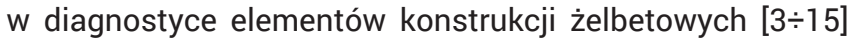
- rysunki 4 i 5.

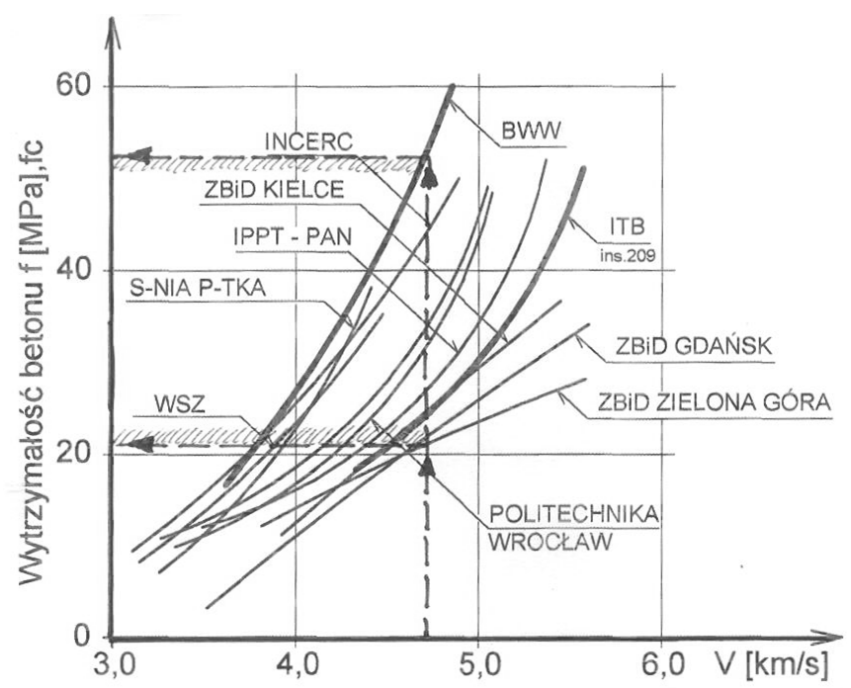

Rys. 4. Przykłady charakterystycznych zależności $\mathrm{f}_{\mathrm{c}}-\mathrm{V}$ dla metody ultradźwiękowej

Fig. 4. Examples of $f_{c}-V$ relations for the ultrasonic method

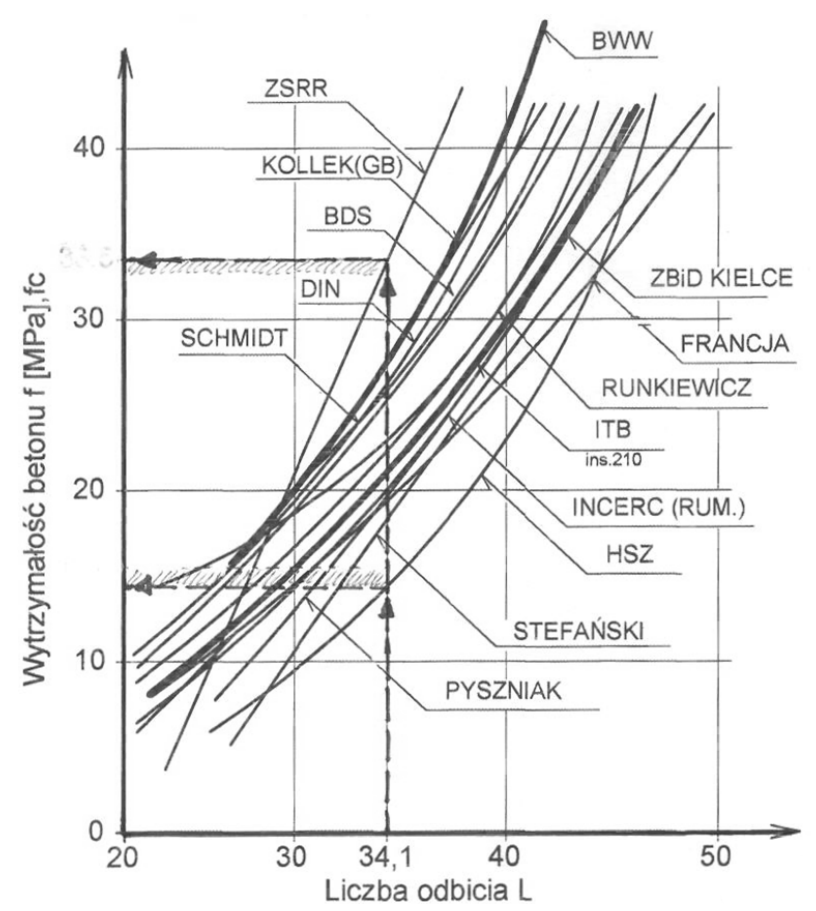

Rys. 5. Przykładowe zależności empiryczne $f_{c}-L$ dla sklerometrów Schmidta typu N

Fig. 5. Examples of $f_{c}-L$ relations for the sclerometric method

Są to zależności specjalne, m.in. dla betonów wysokich wytrzymałości z kruszywem żwirowym oraz betonów z kruszywem keramzytowym, glinoporytowym, drobnoziarnistym, z popiołami lotnymi i innymi dodatkami. Charakter tych zależności wskazu- 
je na bezwzględną konieczność dokładnego lub przybliżonego ustalania ich dla każdego rodzaju betonu w konstrukcji.

Szczególnie wielką rolę w badaniach nieniszczących nowoczesnych betonów w konstrukcjach odgrywają dobory właściwych krzywych korelacyjnych. Jak wykazała dotychczasowa praktyka, zależności empiryczne (krzywe korelacyjne) są bardzo zróżnicowane, a ich błędne stosowania obniżają dokładności ocen nawet o ok. $80 \%$.

Zwiększenia dokładności oceny wytrzymałości betonu w konstrukcji można również uzyskać przez kompleksowe zastosowanie kilku metod pomiarowych. Stosowane równocześnie metody powinny mierzyć różne cechy fizyczne i strukturalne betonu.

Przy analizie otrzymuje się najpierw częściowe statystyczne wskaźniki wytrzymałości według każdej metody, a następnie dokonuje się oceny kompleksowej. Ostateczna ocena statystycznych wskaźników wytrzymałości betonu zależy od wzajemnych związków pomiędzy częściowymi statystycznymi wskaźnikami wytrzymałości, określonymi poszczególnymi metodami $[3 \div 5,15]$.

\section{Zasady badań nieniszczących jakości betonu}

Zasady i warunki stosowania metod nieniszczących do badań betonu w konstrukcjach żelbetowych „in situ” określają normy EN, normy różnych krajów oraz Polskie Normy i instrukcje $[1 \div 15]$.

Zasadniczymi elementami Polskich Norm i instrukcji są zasady:

- realizacji badań elementów i konstrukcji „in situ”,

- interpretacji wyników badań.

W realizacji badań szczególną uwagę kieruje się na wybór miejsc reprezentatywnych dla konstrukcji oraz poprawne wykonywanie pomiarów ultradźwiękowych lub sklerometrycznych. Przy wyborze miejsc pomiarów szczególną uwagę zwraca się na:

- dostateczną grubość i sztywność badanych elementów takich jak: belek, słupów, ścian, płyt, podłoży pod posadzki, itp.,

- zwartą jednorodną strukturę betonu w miejscu wykonywania pomiaru, oraz

- zniszczenia powierzchniowe betonu.

Przy poprawnej interpretacji szczególną uwagę zwraca się na:

- dostateczną liczbę miejsc pomiarowych,

- dobory krzywych korelacyjnych dla badanych betonów, szczególnie wykonywanych według specjalnych technologii,

- wykonywanie odwiertów w elementach w celu dokładniejszego skalowania metod nieniszczących,

- przyjmowanie współczynników korekcyjnych po należytym ich uzasadnieniu,

- ocenę wytrzymałości gwarantowanych, charakterystycznych i obliczeniowych zgodnie z Polskimi Normami,

- kompleksowe stosowanie metod badawczych.

\section{Metody nieniszczące do oceny wytrzymałości betonu dotychczas stosowane w Polsce}

W Polsce metody nieniszczące do oceny wytrzymałości betonu stosowane są od ok. $1960 \mathrm{r}$.

$\mathrm{Na}$ podstawie obszernych badań ponad 2000 próbek oraz badań stosowanych, opracowane zostały 3 instrukcje do takiej oceny betonu [1 $\div 15]$. Po kilku latach intensywnego stosowania metod nieniszczących, opracowano odpowiednie 2 normy PN [1 -15] dla metod sklerometrycznych oraz ultradźwiękowych.
Przykładowe zależności, jakie uzyskano z przeprowadzonych badań ponad 2000 próbek przy położeniu osi przyrządu $\alpha=0$ (ściana) podane są w pracach [1 $\div 15]$ oraz przedstawione na rysunkach 6 i 7 . Rysunek 6 przedstawia wyniki badań wykonanych młotkiem Schmitta typu N, a rysunek 7 - młotkiem typu L. Ponadto dla polskich warunków opracowano zależności empiryczne dla młotków Schmidta typu P i M.

Po dalszych badaniach, analizach porównawczych przeprowadzonych przez wiele ośrodków naukowych oraz uzyskanych z szerokiej praktyki badań technicznych takich elementów jak: fundamenty, ściany, słupy, płyty, belki, kominy, zbiorniki, wieże, silosy, zapory itp. oraz po dodatkowych modyfikacjach przystosowujących je do rozwijających się tech-

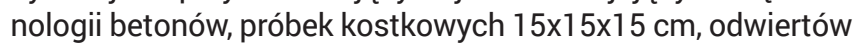
od $\emptyset 5$ do $\varnothing 15 \mathrm{~cm}$, a także nowych zasad oceny jakości i klasyfikacji konstrukcyjnej betonów opracowano metody oceny:

- wytrzymałości średniej,

- wytrzymałości minimalnej,

- odchylenia standardowego wytrzymałości,

- współczynnika zmienności wytrzymałości oraz

- wytrzymałości gwarantowanej (klasy betonu) równej wytrzymałości minimalnej.

Wytrzymałość średnia stanowi statystyczną średnią wytrzymałości betonu w elemencie lub konstrukcji jako zmienną zależną od wyników badań nieniszczących (sklerometrycznych, ultradźwiękowych).

Wytrzymałość minimalna (wytrzymałość gwarantowana) betonu w elemencie lub konstrukcji jako zmienna zależna od rozkładu statystycznego wyników badań nieniszczących (sklerometrycznych, ultradźwiękowych) przy 95\% prawdopodobieństwa nieprzekraczania tej wartości.

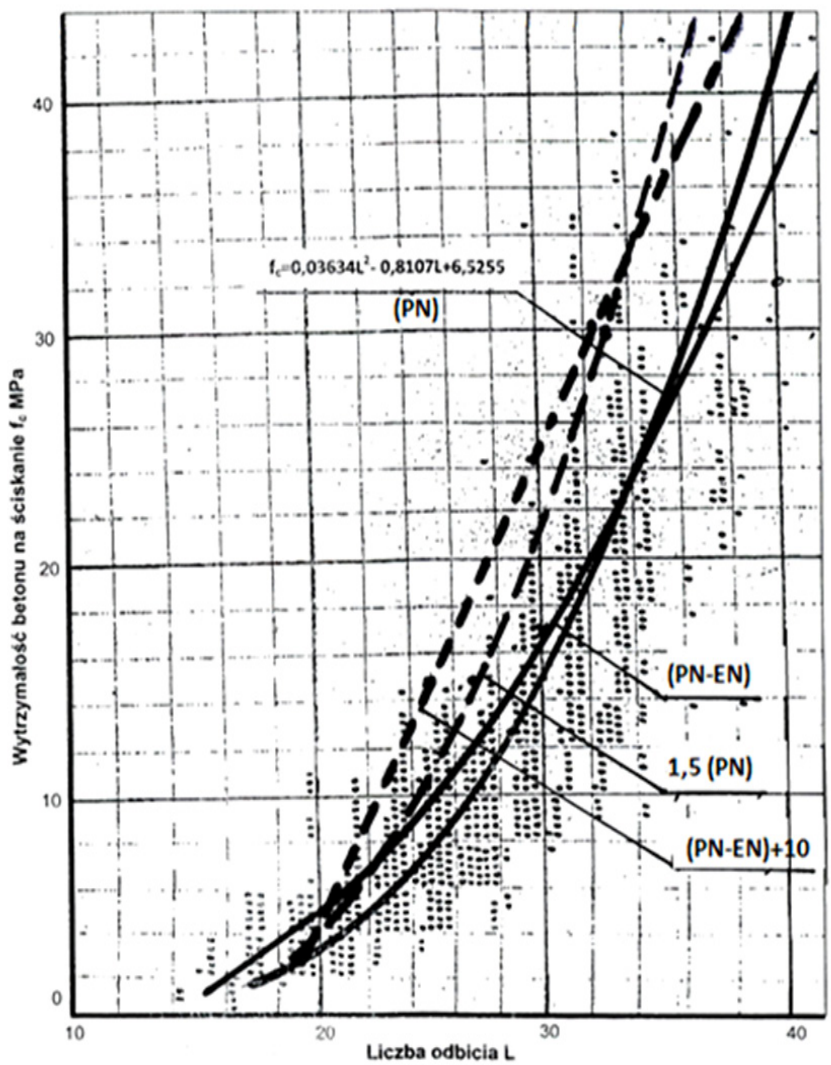

Rys. 6. Zależności empiryczne dla młotków Schmidta typu N $(\alpha=0)$ do oceny wytrzymałości betonu podane dla warunków polskich [7] Fig. 6. Empirical relationships for the rebound hammer type $\mathrm{N}$ $($ alfa $=0)$ for the assessment of the concrete strength applied in Polish conditions [7]

Oznaczenie liczby odbicia przez L wg dotychczasowych Polskich Norm i polskiej literatury. 


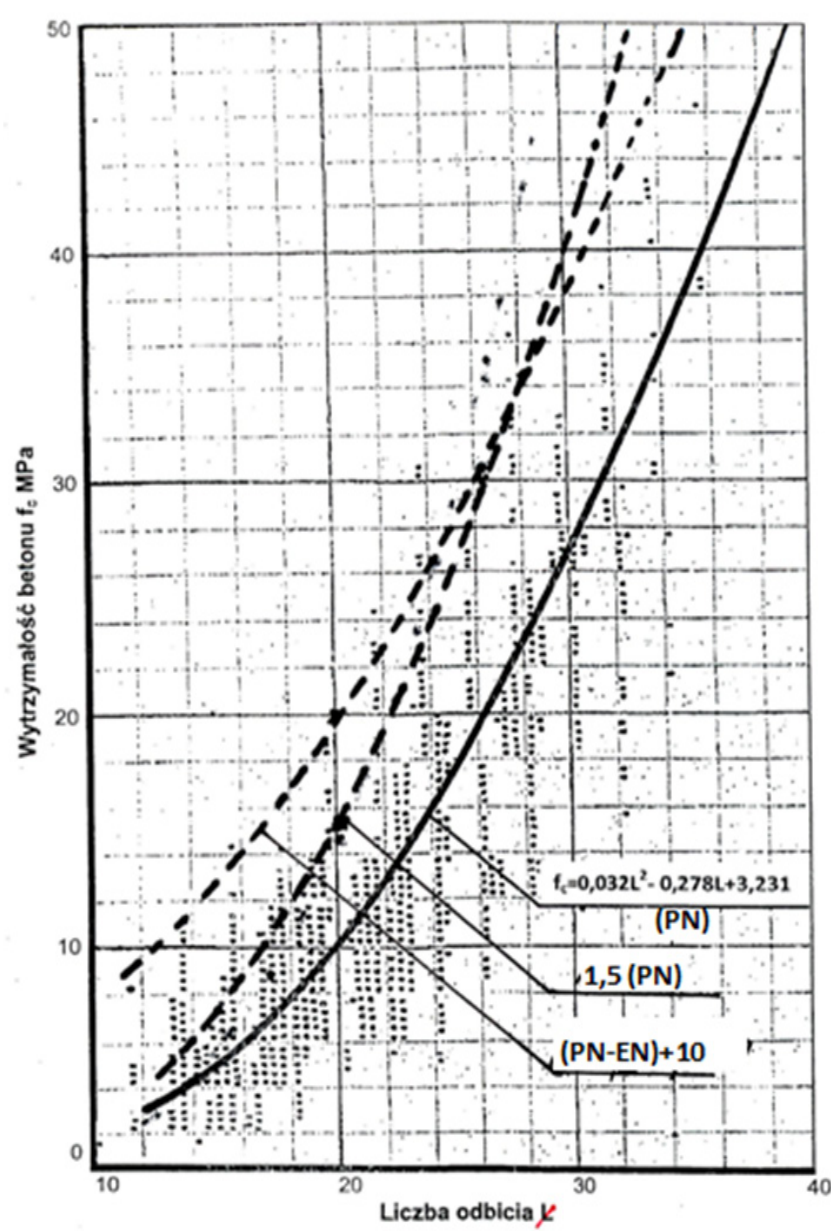

Rys. 7. Zależności empiryczne dla młotków Schmidta typu $L(\alpha=0)$ do oceny wytrzymałości betonu dla warunków polskich [7]

Fig. 7. Empirical relationships for the rebound hammer type $L$ $($ alfa $=0)$ for the assessment of the concrete strength applied in Polish conditions [7]

Natomiast odchylenie standardowe i współczynnik zmienności wytrzymałości są wielkościami statystycznymi wyznaczanymi przy założeniu również rozkładu Gaussa.

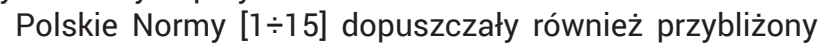
sposób wyznaczania zależności empirycznych dla określonych populacji betonów, wprowadzając do celów ekspertyzowych współczynnik $C_{k}$ do zależności bazowych. Wytrzymałość betonu wyznaczano więc ze wzoru:

$$
f_{c}=C_{k} \cdot f_{c b}
$$

przy ograniczeniu jego stosowania do wartości względnego odchylenia standardowego określonego zależnością:

$$
U_{k} \leq 12 \%
$$

Zwiększone względne odchylenie standardowe obniżało ostateczną ocenę wskaźników wytrzymałości betonu i jej klasy $[1 \div 6]$.

Na rysunkach 6 i 7 pokazano również zależności określone w sposób przybliżony (metoda II) przy współczynniku $\mathrm{C}_{\mathrm{k}}=1,5$ (krzywa 1,5 (PN).

\section{Ocena wytrzymałości betonu w konstrukcji według PN-EN}

Procedury oceny wytrzymałości na ściskanie metodami nieniszczącymi podano w PN-EN 13791[10]. Metody te mogą być stosowane, po przeprowadzeniu wzorcowania na odwiertach. Zostały one opisane w pracach [1 $\div 15]$

Krzywa skalowania proponowana w [10] w przypadku badań sklerometrycznych jest zbliżona do krzywej podanej w instrukcji ITB [14], która jest dolną obwiednią krzywych skalowania. Przebieg krzywej zalecanej w przepisach polskich lepiej odwzorowuje rzeczywisty przebieg zależności, bowiem w badaniach obserwuje się wzrost jej stromości przy wyższej wytrzymałości betonu. Stąd z zasady nie rekomenduje się metody sklerometrycznej do badania betonów wyższych klas, od B60.

W PN-EN 13791[10] przyjmuje się dużą liczbę próbek $n \geq 9$ stanowiących podstawę kalibracji zależności $\mathrm{f}_{\mathrm{R}^{-}} \mathrm{f}_{\mathrm{L}}$. Do przybliżonego skalowania wystarczająca wydaje się być liczba par wyników $n \geq 3$, podobnie jak miało to miejsce w przepisach krajowych stosowanych do metody sklerometrycznej i ultradźwiękowej przy spełnieniu podanych tam warunków.

Parametr przesunięcia krzywej bazowej proponowany przez [10] przy spełnieniu podanych tam warunków zależny jest od współczynnika $k_{1} \geq 1,48$ wynikającego z metody funkcji charakterystycznych i oblicza się go jako wartość różnic $\Delta \mathrm{f}$ funkcji charakterystycznych. W związku z powyższym w pracy [2 i 9] zasugerowano aby wartości przesunięcia $\Delta f$ przyjmować jako górne oszacowanie przedziału ufności wartości średniej $\delta f_{m(n)}$. Wartość ta szacowana jest na poziomie $\pm 0,15 \delta f_{m(n)}$ nie tylko $w$ literaturze krajowej, ale również w badaniach amerykańskich. Wtedy cytując za pracami [1 $\div 15]$ wartość przesunięcia równoległego krzywej bazowej wynosi $\Delta f=0,85 \delta f_{m(n)}$. Analogicznie jak w instrukcji ITB [14] wartość $\delta f_{m(n)}$ można obliczyć operując średnimi wartościami wytrzymałości na ściskanie, wyznaczonymi na próbkach odwiertach $f_{m(n), i s}$ i z podstawowej krzywej bazowej $f_{R}$ (w krajowych przepisach przyjmowano w miejsce współczynnika addytywnego $\Delta$ f współczynnik korekcyjny $C_{k}$ ).

\section{Propozycje dalszego stosowania metod nieniszczących}

Postanowienia normy [10] nie precyzują, przy jakich wartościach rozrzutów wyniki badań można uznać za wiarygodne. Można posiłkować się krajowymi tradycjami w tym zakresie. Jeżeli za podstawowe uzna się badanie wytrzymałości na próbkach odwiertach, to wyniki pomiarów pośrednich uzyskanych w stosunkowo dużej liczbie miejsc konstrukcji mogą stanowić istotną informację w przypadku ograniczonej liczby próbek odwiertów $(n<6)$. Wyniki badań nieniszczących współczynnika zmienności wytrzymałości oznaczonych na podstawie pomiarów pośrednich świadczą, że próbki odwierty są w pełni reprezentatywne i wyniki ich badania należy uznać za miarodajne. W przypadku niespełnienia tych warunków, należy pobrać dodatkowe odwierty z miejsc o zaniżonej wytrzymałości, oszacowanej na podstawie pomiarów sklerometrycznych, a następnie dokonać oceny wytrzymałości betonu w konstrukcji na podstawie zwiększonej liczby próbek-odwiertów.

Przy ocenie wytrzymałości betonu w elementach pochodzących z jednego rodzaju betonu proponuje się, na podstawie dotychczasowych doświadczeń, uwzględnić dotychczasowe zasady Polskich Norm i instrukcji w zakresie oceny wytrzymałości gwarantowanej i klasy betonu [1 $\div 15]$.

Na podstawie dotychczasowych badań dla metody sklerometrycznej można też, przyjmując zależności wg PN-EN [10] lub podane w pracach $[1 \div 7,9,13 \div 15]$, obliczać $f_{\text {min }}$ jako odpowiednik wytrzymałości gwarantowanych wg wzoru:

$$
f_{\min }=f_{c}^{G}=\mathrm{f}_{\mathrm{m}}-1,64 \Delta f
$$

gdzie:

$f_{c}^{G}$ - wytrzymałość gwarantowana betonu w elemencie 
wg $[1 \div 7,9,13 \div 15]$,

$f_{m}$ - wytrzymałość średnia betonu w elemencie obliczana zgodnie z $[1 \div 7,9,13 \div 15]$,

$\Delta f$ - odchylenie standardowe wytrzymałości betonu w elemencie z badań sklerometrycznych wg wzoru:

$$
\Delta f=R_{m} \cdot v_{R} \cdot b
$$

$v_{R}$ - współczynnik zmienności liczb odbicia dla elementu (dla przyjętego oznaczenia liczby odbicia R) wg wzoru:

$$
v_{R}=\frac{s_{R}}{R_{m}}
$$

$b$ - parametr wolny zależności liniowej wg PN-EN [10].

$s_{R}$ - odchylenie standardowe liczb; oblicza się go wg wzoru:

$$
s_{R}=\sqrt{\frac{1}{n-1} \sum\left(R_{n}-R_{m}\right)^{2}}
$$

$R_{m}$ - średnia liczba odbicia dla elementu

$$
R_{m}=\frac{\sum R_{n}}{n}
$$

$n$ - liczba miejsc pomiarowych

Również w sytuacji kontroli betonu stwardniałego istniejącej konstrukcji monolitycznej lub prefabrykowanej w załączniku A do PN-EN 1992 [8] stwierdza się, że wartość $\gamma_{c}$ można zmniejszyć, mnożąc ją przez współczynnik równy 0,85 (w EC 2 nazywany współczynnikiem konwersji $\eta$ ). Jednocześnie wartość $\gamma_{c}$ do której stosuje się to zmniejszenie, może być już zmniejszona ze względu na istniejące odchyłki geometryczne konstrukcji lub zmienność wytrzymałości betonu na ściskanie. Przy czym zredukowana wartość współczynnika, będąca wynikiem wszystkich zmniejszeń, nie powinna być mniejsza niż $\gamma_{c, \text { red4 }}$ którą Załącznik Krajowy do EC 2 zaleca przyjmować równą 1,3 wg PN-EN 1990 [8].

\section{Wnioski}

Do najważniejszych problemów badawczych, związanych z wyznaczaniem wytrzymałości betonu w konstrukcjach żelbetowych z wykorzystaniem metod nieniszczących, należą potrzeby oceny:

- cech wytrzymałościowych i jednorodności betonu w konstrukcjach,

- rys, pęknięć i innych uszkodzeń betonu w konstrukcjach,

- cech reologicznych betonu w konstrukcjach,

- struktury, porowatości i nieciągłości betonu w konstrukcjach,

- korozji betonu w konstrukcjach eksploatowanych.

- napraw i trwałości betonu w elementach,

- połączeń elementów żelbetowych.

W celu podwyższenia jakości betonu i dokładności oceny wytrzymałości nowoczesnych betonów wysokiej jakości należy dokładnie określać właściwe zależności empiryczne w oparciu o odwierty i analizy korekcyjne zgodnie z PN-EN lub dotychczasowymi polskimi doświadczeniami.

Stosowanie nieniszczących metod sklerometrycznych do oceny wytrzymałości betonu w żelbetowych konstrukcjach obiektów modernizowanych wg PN-EN wymaga przystosowania dotychczasowych polskich norm i instrukcji do nowych ustaleń. Powinny one uwzględnić podane zasady PN-EN oraz dotychczasowe bogate doświadczenia krajowe w zakresie stosowania metod nieniszczących do określenia wytrzymałości charakterystycznych i obliczeniowych, a także do oceny jednorodności i innych cech betonu, zarówno w elementach nowych jak i starych obiektów modernizowanych.

\section{Literatura}

[1] Brunarskl L.: Określanie klasy betonu na podstawie diagnostycznych badań konstrukcji, Materiały XIII Ogólnopolskiej konferencja Warsztat Pracy Projektanta Konstrukcji, Ustroń 26-28 lutego 1998 r., tom I, s. 7- 20.

[2] Brunarskl L., Dohojda M.: Diagnostyka wytrzymałości betonu w konstrukcji, seria wydaw. „Prace Naukowe - Monografie, Rozprawy, Studia" ITB, 2015.

[3] Runkiewlcz L.: Diagnostyka i wzmacnianie konstrukcji żelbetowych, Wyd. Politechniki Świętokrzyskiej, Kielce 1999.

[4] Runkiewlcz L.: Wpływ statystycznej analizy wyników badań nieniszczących na ocenę betonu w konstrukcji. Prace ITB - kwartalnik, $\mathrm{nr} 1 / 81$.

[5] Runkiewlcz L.: Badania konstrukcji "in situ" w rzeczoznawstwie budowlanym. Materiały Konferencyjne „Warsztat Pracy Rzeczoznawcy Budowlanego". Wyd. Politechnika Świętokrzyska, Kielce, 1996.

[6] Runkiewlcz L.: Wpływ wybranych czynników na wyniki badań sklerometrycznych betonu. Wyd. ITB, Warszawa, 1994.

[7] Runkiewlcz L.: Sklerometryczna metoda kontroli jakości betonu w konstrukcjach (praca magisterska) Politechnika Warszawska, 1961.
[8] PN-EN 1992-1-1 :2008: Eurokod 2. Projektowanie konstrukcji z betonu. Część I. Reguły ogólne i reguły dla budynków.

[9] Drobiec Ł., Jasiński R., Piekarczyk A.: Diagnostyka konstrukcji żelbetowych. Metodologia, badania polowe, badania laboratoryjne betonu i stali. „Wydawnictwo Naukowe PWN". Warszawa 2010.

[10] PN-EN 13791:2008 Ocena wytrzymałości betonu na ściskanie w konstrukcjach prefabrykowanych wyrobach betonowych.

[11] PN-B-06262:1974 Nieniszczące badania konstrukcji z betonu. Metoda sklerometryczna badania wytrzymałości betonu na ściskanie za pomocą młotka Schmidta typu N.

[12] PN-EN 12504-2:2002; PN-EN 12504-2:2002/Ap1:2004 Badania betonu w konstrukcjach. Część 2: Badanie nieniszczące. Oznaczanie liczby odbicia.

[13] Instrukcja ITB nr 361/99 Zasady oceny bezpieczeństwa konstrukcji żelbetowych. ITB, Warszawa $1999 \mathrm{r}$.

[14] Instrukcja ITB 210/1977 Instrukcja stosowania młotków Schmidta do nieniszczącej kontroli jakości betonu.

[15] Materiały Konferencji Badań Nieniszczących, Wyd. SIMP, lata 19902014. 